\title{
Microbiological Quality and Antibiotic Susceptibility of Isolates from Fish and Poultry Feeds
}

\author{
Ifeanyi O. C. Obiajuru ${ }^{1, ~ *}$, Chidinma A. Ikpeama ${ }^{2}$, Immaculata O. Uduchi ${ }^{3}$ \\ ${ }^{1}$ Department of Medical Microbiology \& Parasitology, Faculty of Medicine, Imo State University, Orlu Campus, Imo State, Nigeria \\ ${ }^{2}$ Department of Animal \& Environmental Biology, Faculty of Science, Imo State University, Owerri, Imo State, Nigeria \\ ${ }^{3}$ Department of Medical Microbiology \& Parasitology, Imo State University Teaching Hospital, Orlu Imo State, Nigeria
}

\author{
Email address: \\ eanyi_oc@yahoo.co.uk (I. O. C. Obiajuru)
}

\section{To cite this article:}

Ifeanyi O. C. Obiajuru, Chidinma A. Ikpeama, Immaculata O. Uduchi. Microbiological Quality and Antibiotic Susceptibility of Isolates from Fish and Poultry Feeds. American Journal of Life Sciences. Vol. 3, No. 6, 2015, pp. 402-407. doi: 10.11648/j.ajls.20150306.14

\begin{abstract}
The microbiological quality and antibiotic susceptibility of bacterial isolates from fish and poultry feeds used in Imo State, South Eastern Nigeria was studied between January and July, 2015. A total of 13 different feeds comprising 3 fish feeds and 10 poultry feeds were collected from different marketers Imo State and examined bacteriologically by culture technique. Seven genera of bacteria: Staphylococcus species, Bacillus species, Campylobacter jejuni, Listeria species, Proteus mirabilis, Escherichia coli, and Salmonella species, as well as 2 genera of fungi: Aspergillus species and Penicillinum species were isolated from the feeds. Statistical analysis of the data showed significant difference $(\mathrm{p}<0.05)$ in the bacteriological and mycological quality between local and industrial processed feeds. There was no significant difference $(p>0.05)$ in the bacteriological and mycological quality between fish and poultry feeds. Antibiotic susceptibility test revealed that Ciprofloxacin exhibited the highest antibacterial effects (grow inhibition) on most of the bacterial isolates than other antibiotics used. This study has revealed that fish and poultry feeds are potential sources of microbial infections for fish and poultry as well as human handlers and consumers of fish and poultry products in Imo State. The Government and public health operators in the State should educate the population on protective measures and also carry out routine supervision and regulation of production and use of these products.
\end{abstract}

Keywords: Microbiological Quality, Antibiogram Bacteria Fish, Poultry Feeds

\section{Introduction}

Poultry is the fastest growing source of meat in Nigeria. It contributes over $1 / 4$ of all the meat produced and consumed in the country. Similarly, fish farming is expanding rapidly in the country, especially in Southern Nigeria. Globally, over $1 / 5$ of humans depend on fish as their primary source of protein. In Jamaica, Aiken et. al., (2002) reported that reported that annual production of food fish from aquaculture rose from a low of $0.1 \mathrm{t}$ in 1976 to just over 5,000 $\mathrm{t}$ in 2000 . Elsewhere, Klinger and Floyd (2009) stated that fish culture as a hobby or business is well established in Florida. According to te World Fish Centre (2003), fish is a key ingredient on the global menu, a vital factor in the global environmental balance and an important basis for livelihoods worldwide. The concentration of cholesterol in red meat is high, for this reason, nutritionists and health workers encourage adults to eat more of fish and poultry meat than red meat. This has contributed immensely to increased utilization of poultry and fish as well as interest in poultry and fish farming. Poultry provides eggs and meat for human consumption. It includes all domesticated birds used for these purpose but in Nigeria the word most commonly refers to chickens. Different brands of poultry and fish feeds exist in Nigeria for different functions. These include Growers, Finishers, Layers starter among others. Feeds supply livestock with nutrients required for their body functions. Quality feed for livestock is very important for the maintenance of physiological functions and defense mechanism against diseases and infections. Feed quality is specified on basis of the nutritional value of every individual feed component. Micro-organisms such as bacteria and fungi growing on livestock feed affect their quality.

Animal feeds are sometimes exposed to contamination from environmental pollution, handling processes and other sources. Some may contain endogenous toxins arising principally from 
specific primary and secondary substances produced by fodder plants. Feed toxins include compounds of plant and microbial origin. Feed materials often contain non-nutritional contaminants that may reduce the nutritional value or exert adverse health effects in animals. Fungi spores, may remain dominant in processed feeds until more favourable condition which support their proliferation. Contamination of feeds with moulds or bacteria may decrease their nutritional value and affects animal health. Contaminated feeds may help to distribute pathogens to humans especially in tropical countries where temperature and relative humidity are high.

Poultry feeds have been implicated in various bacterial diseases with varied pathological manifestations. Salmonella infections of poultry, has been reported to be of critical importance in Nigeria. Studies have shown that sources of Salmonella infection in poultry include contaminated products, feeds and feed ingredients, human wastes, mouse and rat droppings among others (Ohalete et al., 2012).

\section{Materials and Methods}

Study area.

This study was carried out in Imo State, South - Eastern Nigeria. Imo State lies between latitudes $5^{\circ} 30^{\prime}$ and $6^{\circ} 15^{\prime}$ North, longitude $6^{\circ} 38^{\prime}$ and $7^{\circ} 18^{\prime}$ East. It is bound on the West by Delta State, on the North by Anambra State, on the South by Rivers State and on the East by Abia State. It comprises of 3 geo - political zones: Orlu, Owerri and Okigwe.

Imo State is densely populated with men and women of all ages. About $30 \%$ of the working class dwellers in Imo State are crop and animal farmers. Fish and livestock are widely produced, marketed and consumed in different parts of Imo State.

\section{Study Samples}

The samples used for this study are industrial and locally produced livestock and fish feeds: Top Feed Grower Mash (Top GM), Top Feed Layer Mash (Top LM), Top Feed Broiler Finisher (Top BF), Livestock Layer Mash (LS LM), Life Stock Broiler Starter (LS BS), Livestock Broiler Finisher (LS BF), Guinea Broiler Starter (Guinea BS), Guinea Broiler Finisher (Guinea BF), Guinea Layer Mash (Guinea LM). Local Poultry Feed (Local PF), Vita Fish Starter (Vita FS), Vita Fish Finisher (Vita FF) and Euro Fish Finisher (Euro FF). The samples were purchased from standard shops and open markets in Owerri and Orlu, Imo State. Five samples ( 3 from Owerri and 2 from Orlu) of each feed were purchased from different marketers. They were transported in sterile containers to the Microbiology Laboratory, Imo State University Teaching Hospital Orlu and examined within 2 hours.

\subsection{Microbiological Quality of Test Samples}

Samples of the selected poultry fish feed were examined for bacteriological and mycological quality by culture technique, using streaking and spread - plate methods as in
Chesbrough (2002), Obiajuru and Ozumba (2009). The media used were Mueller Hinton agar, Chocolate agar, MacConkey agar, Campylobacter selective agar, Salmonella \& Shigella agar, Listeria Selective agar and Saboraud Dextrose agar. One set of Saboraud dextrose agar plates were incubated at $37^{\circ} \mathrm{C}$ for 24 hours and another set was incubated at room temperature in a fume cupboard and examined daily for 7days. Chocolate agar plates were incubated anaerobically at $37^{\circ} \mathrm{C}$ for 24 hours using anaerobic gas jar and other inoculated plates were incubated aerobically at $37^{\circ} \mathrm{C}$ for 24 hours. The incubated plates were examined for microbial growth. Those showing no microbial growth were re - incubated for another 24 hours and examined for microbial growth. Discrete colonies of each isolate on the different plates were sub cultured on fresh agar plates and incubated at $37^{\circ} \mathrm{C}$ for 24 hours to obtain pure cultures of all isolates. Pure culture of the isolates were identified and used for antimicrobial susceptibility tests.

\subsection{Microbial Plate Counts}

Two samples of each selected poultry and fish feed were used to determine the total heterotrophic bacterial and fungal counts. The total bacterial and fungal counts were determined using spread - plate and colony counter as in Obiajuru and Ozumba (2009). Each sample was processed by serial dilution by dissolving $1 \mathrm{~g}$ of each sample in $9 \mathrm{ml}$ maximum recovery diluent to obtain 1 in 10 dilution. $1 \mathrm{ml}$ of this was diluted in $9 \mathrm{ml}$ of the diluent and so on to obtain 1 in $10^{2}, 1$ in $10^{3} \ldots \ldots 1$ in $10^{6}$ dilutions. $0.1 \mathrm{ml}$ of the various dilutions of each sample was inoculated on Mueller Hinton agar plates using spread plate technique. The inoculated plates were incubated for 24 hours at $37^{\circ} \mathrm{C}$. They were examined and all bacterial colonies were counted using colony counter. Acceptable colony counts were those ranging from 30 to $300 \mathrm{cfu}$.

\subsection{Antibiotic Susceptibility of Test Isolates}

The antimicrobial agents used for this study are commercially prepared single antibiotic discs containing Ciprofloxacin (Ciproxin) $5 \mu \mathrm{g}$ and Levofloxacin (Levomax) $5 \mu \mathrm{g}$, and laboratory prepared single discs containing Rifampicin $10 \mu \mathrm{g}$, Ampiclox $30 \mu \mathrm{g}$, Erythromycin $10 \mu \mathrm{g}$ and

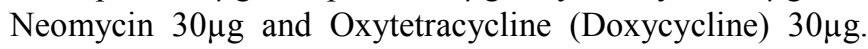
The antibiotics used to prepare the discs and the commercially prepared discs were obtained from accredited pharmaceutical shops and suppliers of Laboratory reagents in Orlu and Owerri. The bacterial isolates were subjected to antibiotic susceptibility test using disc paper diffusion method as in Chesbrough (2002), Obiajuru and Ozumba, (2009). The discs were placed $16 \mathrm{~mm}$ away from each other, using sterile forceps. The plates were incubated at $37^{\circ} \mathrm{C}$ overnight and examined for bacterial growth inhibition. The zone of growth inhibition around each sensitive antibiotic disc was measured using a transparent metric rule.

\subsection{Method of Statistical Analysis}

The data obtained from this study were analysed using 
simple percentage analysis, Chi square and Analysis of variance (ANOVA) as in Philip, (2002).

\section{Results}

Microbiological quality of fish and poultry feeds.

The study showed that 7 genera of bacteria: Staphylococcus species, Bacillus species, Campylobacter jejuni, Listeria species, Proteus mirabilis, Escherichia coli, Salmonella species and 2 genera of fungi: Penicillinium species and Aspergillus species, were involved in contamination of fish and poultry feeds sold and used by farmers in Imo State. Table 1 summarized the prevalence of bacteria and fungi in fish and poultry feeds. As shown, the most prevalent bacteria in poultry feeds was Escherichia coli $(29.2 \%)$ while the least prevalent bacteria was Bacillus $(10.8 \%)$. The most prevalent fungus was Penicillinium species (9.2\%). The total heterotrophic Bacterial (THB) and Fungal (THF) counts of fish and poultry feeds used in this study are summarized in tables 2 and 3 respectively. Analysis of the data using chi square showed significant difference ( $p$ $<0.05)$ in the bacteriological and mycological quality between local and industrial processed poultry feeds. There was no significant difference $(p>0.05)$ in the bacteriological quality between fish and poultry feeds. As shown, the highest bacterial counts $\left(1.08 \times 10^{6}\right.$ and $\left.1.74 \times 10^{5}\right)$ were observed in locally processed poultry feeds while the least bacterial count $\left(1.1 \times 10^{4}\right)$ was observed on Guinea Broiler Starter feed. Similarly, the highest heterotrophic fungal count $\left(8.4 \times 10^{4}\right)$ was observed in locally processed poultry feed while the least fungal count $\left(3.7 \times 10^{3}\right)$ was observed on industrially processed poultry feed (Top GM feed).

Table 4 shows the antibacterial effects (growth inhibitory) of selected antibiotics on the test bacterial isolates while Fig 1 summarizes their susceptibility pattern. As shown, Ciprofloxacin inhibited growth of $90.9 \%$ Staphylococcus aureus, $85.7 \%$ Bacillus species, 83.3\% Listeria and Proteus species, 78.9\% Escherichia coli, 70\% Campylobacter jejuni, and $66.7 \%$ Salmonella species. The mean zone of growth inhibition exhibited the on the isolates by Ciprofloxacin ranged from $20.0 \mathrm{~mm}$ (Bacillus and Proteus species) to $25.4 \mathrm{~mm}$ on Listeria species. Erythromycin inhibited growth of only $10.5 \%$ Escherichia coli and 25\% Proteus mirabilis with mean zones of growth inhibition $15 \mathrm{~mm}$ and $12 \mathrm{~mm}$ respectively. Rifampicin exhibited $100 \%$ growth inhibitory effects on Bacillus species with mean zone of growth inhibition $18.5 \mathrm{~mm}$.

All Bacillus species, Staphylococcus aureus, Salmonella, Listeria species and Campylobacter isolates were resistant to Erythromycin. Analysis of the data using Chi - square shows significant difference $(\mathrm{p}<0.05)$ in the susceptibility pattern between fluoroquinolones and amynoglycosides / macrolides.

Table 1. Prevalence of Bacteria and fungi species in poultry and fish feeds.

\begin{tabular}{|c|c|c|c|c|c|c|c|c|c|c|}
\hline \multirow[b]{2}{*}{ Sample } & \multirow{2}{*}{$\begin{array}{l}\text { Number } \\
\text { Exam }\end{array}$} & \multicolumn{7}{|c|}{ Number Infected (\%) } & \multicolumn{2}{|l|}{ Fungi } \\
\hline & & $\begin{array}{l}\text { Staphylococcus } \\
\text { aureus }\end{array}$ & $\begin{array}{l}\text { Bacillus } \\
\text { species }\end{array}$ & $\begin{array}{l}\text { Campylobacter } \\
\text { jejunum }\end{array}$ & $\begin{array}{l}\text { Listeria } \\
\text { species }\end{array}$ & $\begin{array}{l}\text { Escherichia } \\
\text { coli }\end{array}$ & $\begin{array}{l}\text { Proteus } \\
\text { mirabilis }\end{array}$ & $\begin{array}{l}\text { Salmonella } \\
\text { sp }\end{array}$ & Penicillinum & $\begin{array}{l}\text { Aspergillus } \\
\text { sp }\end{array}$ \\
\hline Top GM & 5 & - & - & 2 & 1 & 3 & 2 & 1 & 2 & - \\
\hline Top LM & 5 & - & 2 & - & - & 2 & - & 1 & 1 & 1 \\
\hline Top BF & 5 & 2 & - & 1 & 2 & 1 & 1 & - & - & - \\
\hline LS BS & 5 & - & 1 & - & - & 2 & 1 & 2 & 1 & 1 \\
\hline LS BF & 5 & 2 & - & - & 2 & 2 & - & 1 & - & - \\
\hline Vita FF & 5 & - & - & - & - & 2 & 2 & 1 & - & - \\
\hline Vita FS & 5 & 1 & - & 1 & 2 & 1 & 1 & - & - & - \\
\hline Euro FF & 5 & - & 1 & 1 & - & 2 & 2 & - & - & - \\
\hline Guinea BS & 5 & 2 & - & 2 & - & - & - & 1 & - & - \\
\hline Guinea BF & 5 & 1 & - & 1 & 2 & 1 & 1 & - & 1 & 1 \\
\hline Guinea LM & 5 & 2 & - & - & 2 & - & 1 & - & - & 1 \\
\hline Local PF & 5 & - & 1 & 2 & - & 1 & 1 & - & 1 & - \\
\hline
\end{tabular}

$\mathrm{P}<0.05$.

Table 2. Total Heterotrophic Bacterial count.

\begin{tabular}{|c|c|c|c|c|c|}
\hline \multirow{2}{*}{ Sample } & \multirow{2}{*}{ Dilution Factor } & \multicolumn{3}{|c|}{ Number of Colonies } & \multirow{2}{*}{ Total Heterotrophic Bacterial count (cfu/ml) } \\
\hline & & Plate 1 & Plate 2 & Mean & \\
\hline Top BF & $1 / 10^{3}$ & 167 & 161 & 164 & $1.64 \times 10^{5}$ \\
\hline Top BF & $1 / 10^{2}$ & 132 & 124 & 128 & $1.28 \times 10^{4}$ \\
\hline Top LM & $1 / 10^{2}$ & 205 & 201 & 203 & $2.03 \times 10^{4}$ \\
\hline Top LM & $1 / 10^{2}$ & 108 & 118 & 113 & $1.13 \times 10^{4}$ \\
\hline Top GM & $1 / 10^{3}$ & 159 & 157 & 158 & $1.58 \times 10^{5}$ \\
\hline Top GM & $1 / 10^{3}$ & 99 & 93 & 96 & $9.6 \times 10^{4}$ \\
\hline L/S BS & $1 / 10^{2}$ & 184 & 180 & 182 & $1.82 \times 10^{4}$ \\
\hline L/S BS & $1 / 10^{3}$ & 84 & 92 & 88 & $8.8 \times 10^{4}$ \\
\hline $\mathrm{L} / \mathrm{S} B / \mathrm{F}$ & $1 / 10^{2}$ & 171 & 169 & 170 & $1.70 \times 10^{4}$ \\
\hline $\mathrm{L} / \mathrm{S} \mathrm{B} / \mathrm{F}$ & $1 / 10^{3}$ & 69 & 53 & 61 & $6.1 \times 10^{4}$ \\
\hline L/S LM & $1 / 10^{3}$ & 123 & 129 & 126 & $1.26 \times 10^{5}$ \\
\hline
\end{tabular}




\begin{tabular}{llllll}
\hline \multirow{2}{*}{ Sample } & \multirow{2}{*}{ Dilution Factor } & Number of Colonies & & Mean & \multirow{2}{*}{ Total Heterotrophic Bacterial count (cfu/ml) } \\
\cline { 3 - 5 } & $1 / 10^{3}$ & 104 & Plate 2 & 108 & $1.08 \times 10^{5}$ \\
\hline L/S LM & $1 / 10^{2}$ & 102 & 108 & 105 & $1.05 \times 10^{4}$ \\
VITA FF & $1 / 10^{3}$ & 71 & 77 & 74 & $7.4 \times 10^{4}$ \\
VITA FF & $1 / 10^{2}$ & 93 & 87 & 90 & $9.0 \times 10^{4}$ \\
VITA FS & $1 / 10^{3}$ & 60 & 72 & 66 & $6.6 \times 10^{4}$ \\
VITA FS & $1 / 10^{2}$ & 110 & 106 & 108 & $1.08 \times 10^{4}$ \\
EURO FF & $1 / 10^{2}$ & 137 & 123 & 130 & $1.3 \times 10^{4}$ \\
EURO FF & $1 / 10^{3}$ & 114 & 117 & $1.17 \times 10^{5}$ \\
GUINEA BS & $1 / 10^{2}$ & 115 & 105 & 110 & $1.1 \times 10^{4}$ \\
GUINEA BS & $1 / 10^{3}$ & 150 & 152 & 148 & $1.48 \times 10^{5}$ \\
GUINEA BF & $1 / 10^{2}$ & 140 & 104 & 146 & $1.46 \times 10^{4}$ \\
GUINEA BF & $1 / 10^{2}$ & 100 & 125 & 102 & $1.02 \times 10^{5}$ \\
GUINEA LM & $1 / 10^{3}$ & 131 & 175 & 174 & $1.28 \times 10^{5}$ \\
GUINEA LM & $1 / 10^{3}$ & 173 & 115 & 108 & $1.74 \times 10^{5}$ \\
LOCAL PF & $1 / 10^{3}$ & 101 & & $10^{6}$ \\
LOCAL PF & $1 / 10^{4}$ & & &
\end{tabular}

$\mathrm{P}<0.05$.

Table 3. Total Heterotrophic Fungal count.

\begin{tabular}{llllll}
\hline \multirow{2}{*}{ Sample } & \multirow{2}{*}{ Dilution Factor } & \multicolumn{2}{l}{ Number of Colonies } & \multirow{2}{*}{ Total Heterotrophic Fungal count (cfu/ml) } \\
\cline { 3 - 5 } & $1 / 10^{2}$ & Plate $\mathbf{1}$ & Plate 2 & Mean & \\
\hline Top GM & $1 / 10^{2}$ & 35 & 42 & 43 & $4.3 \times 10^{3}$ \\
Top GM & $1 / 10^{2}$ & 45 & 39 & 37 & $3.7 \times 10^{3}$ \\
Top LM & $1 / 10^{2}$ & 63 & 47 & 46 & $4.6 \times 10^{3}$ \\
LS BS & $1 / 10^{2}$ & 58 & 67 & 65 & $6.5 \times 10^{3}$ \\
Guinea B/F & $1 / 10^{2}$ & 34 & 62 & 60 & $6.0 \times 10^{3}$ \\
Guinea LM & $1 / 10^{3}$ & 81 & 38 & 36 & $3.6 \times 10^{3}$ \\
LOCAL PF & & & 87 & 84 & $8.4 \times 10^{4}$ \\
\hline
\end{tabular}

$\mathrm{P}<0.05$.

Table 4. Antibacterial Effects of Selected Antibiotics on Test Isolates.

\begin{tabular}{|c|c|c|c|c|c|c|c|c|}
\hline \multirow{2}{*}{ Isolates } & \multirow{2}{*}{ Number Tested } & \multicolumn{7}{|c|}{ Mean Zone of Growth Inhibition (mm) } \\
\hline & & Ciproxin & Levofloxacin & Rifampicin & Ampiclox & Erythromycin & Doxycyclin & Neomycin \\
\hline Staphylococcus aureus & 11 & 22.5 & 26.0 & 23.2 & 15.0 & 0.0 & 12.0 & 14.0 \\
\hline Bacillus species & 7 & 20.0 & 22.5 & 18.5 & 12.5 & 0.0 & 10.0 & 12.0 \\
\hline Campylobacter jejuni & 10 & 21.6 & 20.4 & 24.5 & 10.4 & 0.0 & 0.0 & 0.0 \\
\hline Listeria species & 12 & 25.4 & 24.5 & 18.0 & 12.6 & 0.0 & 10.5 & 0.0 \\
\hline Escherichia coli & 19 & 24.0 & 28.2 & 22.5 & 18.5 & 15.0 & 12.2 & 15.5 \\
\hline Proteus mirabilis & 12 & 20.0 & 26.4 & 20.0 & 20.0 & 12.0 & 14.0 & 12.5 \\
\hline Salmonella species & 9 & 20.5 & 20.0 & 16.5 & 10.5 & 0.0 & 0.0 & 14.0 \\
\hline
\end{tabular}

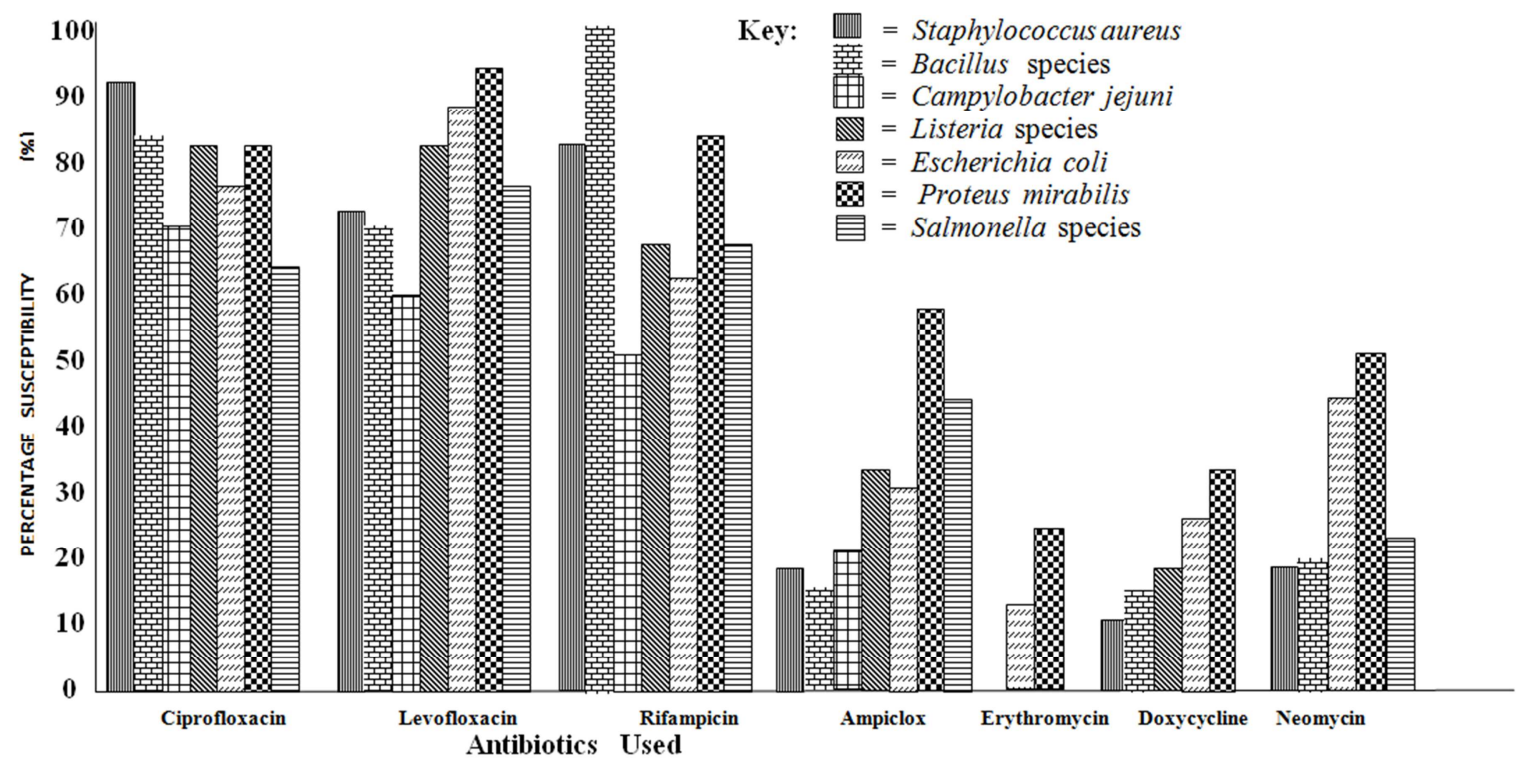

Fig. 1. Antibiotic Susceptibility of the Test Isolates. 


\section{Discussion of Findings}

Human and livestock food materials contain bacteria and/or fungi, some are normal flora of the raw materials used in production of food, others are contaminants introduced during processing and handlings. Some of these organisms are responsible for spoilage and poisoning of human and livestock food. The present study implicated 7 genera of bacteria: (Staphylococcus species, Bacillus species, Campylobacter jejuni, Listeria species, Escherichia coli, Salmonella species and Proteus) and 2 genera of fungi (Aspergillus and Penicillinum). This finding agrees with report of previous workers (Uwaezuoke, et al., 2000) who reported the presence of bacteria species in livestock feeds. Some of the bacteria isolated in the present study are responsible for human infections via the gastrointestinal tract. Salmonella species causes typhoid and paratyphoid fever in humans. Previous studies (Obiajuru et al., 2015) reported emergence of campylobacteriosis in Imo State and related this findings to increasing prevalence of Campylobacter jejuni in public water, fish, beef and chicken sold in the area. The microorganisms isolated from fish and poultry feeds in the present study are capable of infecting both fish and poultry birds that consume the feeds. When ingested by these farm animals, the organisms grow and multiply in the livestock which in turn will be consumed by humans. Thus, not only the livestock are at risk but also humans who feed on the infected livestock. Public health authorities should therefore monitor and regulate production, marketing and use of livestock feeds to control possibility of infection and disease outbreak through it. Human food borne infections is a growing public Health problem in many parts of the world especially the developing Countries like Nigeria. Thus Public Health inspectors should include inspection of Fish and livestock feeds in their routine duties. Feeds contaminated with pathogenic microbes such as Salmonella, Campylobacter and Vibrio species should be decontaminated before use or destroyed outright.

The fungal isolates (Aspergillus and Penicillinum) in the present study are among organisms commonly implicated in the fermentation and steeping of cereals for the production of livestock feeds and human food. This finding agrees with previous workers (Banigo and Mueller, 1972), who isolated Fusarium species, Aspergillus, Penicllinum, etc. in the fermentation and steeping of cereals for the production of human food and livestock feeds. It is likely that these fungi contaminated the test samples through the raw materials used for the production or the techniques used in processing of these materials into final products. The health implications of these fungi are many. Aspergillus species cause infection which resemble tuberculosis in symptoms but does not respond to usual treatments for tuberculosis. In rural communities and places without adequate diagnostic facilities for fungal infections, health workers treat such patients as tuberculosis patients only to end up wasting drugs and money and finally losing the patient. Furthermore, Aspergillus produce aflatoxins which cause varied diseases including blood poisoning in humans. Diagnosis and treatment of human victims of aflatoxins is not easily achieved and often, cases terminate in death of patient. Muller, (1990) reported that Toxin producing fungi are dangerous, especially those producing aflatoxins, patulins, and trichotecens which are strongly carcinogenic and mutagenic.

The antibiotics used in this study are commonly used clinically in Imo State to treat infected humans. Some of the bacterial isolates exhibited remarkable degree of antibiotic resistance. One of the challenges facing clinicians in developing countries is management of antibiotic resistant bacterial infections. A number of factors such as beta lactamase production and drug abuse among other factors are responsible for this growing health challenge. Humans who are directly and indirectly in contact with these feeds contaminated with antibiotic resistant bacteria are at risk of acquiring antibiotic resistant bacteria infection. Previous workers (Gill and Best, 1998) reported that antibiotic resistant bacteria have been transferred to humans from farm produce. Other workers (Austin and Austin, 1989; Ogbulie and Okpokwasili, 1998) observed that most antibiotics approved for use in aquaculture and animal husbandry by Food and Drug Administration Authorities in some countries are also used to treat humans. These workers observed that regular exposure of micro-organisms to small doses of antibiotics via farm animals result to emergence of antibiotic resistant strains which in turn infect humans leading to treatment failure, delays, waste of drugs and resources.. The antibacterial effects of the sensitive antibiotics on the bacterial isolates in the present study are similar to that observed on clinical bacterial isolates in previous studies (Obiajuru and Chukuezi, 2011, Anyadoh - Nwadike, 2015). This finding shows that irrespective of the growing prevalence of antibiotic resistant bacteria in the country, hope is not lost on the efficacy of drugs commonly used in Nigeria to eliminate bacteria found in humans, fish and poultry feeds. Humans and livestock exposed to bacterial infections emanating from contaminated livestock feeds will benefit from many antibiotics such as the fluoroquinolones and amino-glycosides. The manufacturers of the feeds should take advantage of the study and use the antibiotics only when necessary and in the right dose to reduce the risk of developing antibiotic resistant strains.

The present study has shown that fish and poultry feed are potential sources of livestock and human infections. Apart from livestock, people at risk include farmers and consumers of fish and poultry products. Improved farm management practice, genetic selection, improved feeding and use of antibiotic therapeutic agents to treat bacterial diseases of farm animals, will play major roles to control the infections. Government should also legislate and monitor production, marketing and use of fish and poultry feeds to ensure quality and standard. Regular seminars and workshops should be 
organized for farmers, marketers and local manufacturers of fish and poultry feeds to educate them on possible health hazards associated with these feeds and possible control measures.

\section{Acknowledgements}

We are grateful to Amarachi Obiajuru of Uzondu Medical Laboratory Owerri, Rachael Oparaji of Imo State University Teaching Hospital Orlu and Chukwudiaru Chinelo for their various assistance in collection and analysis of samples for this study.

\section{References}

[1] Aiken, K. A., Morris, D., Hanley, F. C. and Manning, R. (2002): Aquaculture in Jamaica. Naga, World Fish Centre Quarterly 25(3 \& 4): 10-16.

[2] Anyadoh - Nwadike, S. O., Okorondu, S. O., Obiajuru, I. O. C., Nwadike, P. O., Nwaokorie, F. O. and Akerele, J. O. (2015): Comparative Study of the Prevalence and Antibiogram of Bacterial isolates from the urinary and genital tracts of Ante - Natal patients. IOSR Journal of Pharmacy and Biological Sciences. e- ISSN: 2278 - 3008, p - ISSN: $2319-7676.10$ (1): 15-19.

[3] Austin, B. and Austin, D. A. (1989): Methods for the Microbiological Examination of Fish and Fish Products. Ellis Horwood Publishers. Chichester.

[4] Banigo, E. O. I. and Mueller, H. G. (1972): Manufacture of Ogi: A Nigerian Fermented cereal porridge; Comparative Evaluation of Com - Sorghium and Millet. Can Lust Food Sci. Technology J. 5: 217-221.

[5] Chesbrough, M. (2002): Medical Laboratory Manual for Tropical countries vol II: Microbiology. Tropical health Technology/Butterworths and Co Ltd. Cambridge/Sevanaks.

[6] Gill, C. and Best, P. (1998): Antibiotic resistance in U. S. A. Scientists ti look more closely. Feed International. 19 (8): 1617.
[7] Klinger, RE and Floyd R. F (2009): Introduction to Freshwater Fish parasites. Fisheries and Aquatic Sciences $(S F R C)$. University of Florida IFAS Extension EDIS. p. 1-12. http:edis.ifas.ufl.edu/FAO41.

[8] Mueller, H. G. (1990): Traditional Cereal processing in Nigeria and Ghana. Journal of Agricultural Science 3: 187195.

[9] Obiajuru, I. O. C and E. I. Nnadi (2010): The Pollution Status and Effects of Seasonal Changes in Rivers within Imo River Basin. Research Journal of Health Sciences 1 (1): 55-69.

[10] Obiajuru I. O, C. and Ozumba, U. C. (2009): Laboratory Methods for Medical Microbiology \& Parasitology. Lifeway Amalgamations. Owerri. ISBN: 25799107. p. 183.

[11] Obiajuru, I. O. C. and Chukuezi, A. B. (2012): Microbiological Assessment of ENT infections and diseases: Clinical case study at Orlu Imo State, Nigeria. Journal of Research in Nursing and Midwifery ISSN 2315-568x.

[12] Obiajuru, I. O. C., Anolue, F. C. and Adogu, P. O. U (2015): Emergence of Campylobacteriosis and its Antibiotic Susceptibility Pattern in Orlu, South - Eastern Nigeria. Caribbean Journal of Science and Technology. ISSN: $0799-$ 3757. 3: 798-804.

[13] Ogbulie, J. N. and Okpokwasili, G. C. (1998): Efficacy of Chemotherapeutic agents in controlling bacterial disease of cultured fish. Journal of Aquaculture in the Tropics 13: 61-72.

[14] Ohalete, C. N., Dozie, I. N. S., Obiajuru, I. O. C and Ekeh, I. H. (2012): Studies on the Ecology of Salmonella bacilli in Owerri metropolis, Imo State Nigeria. Global Research Journal of Science ISSN: 2276-8300.

[15] Philip, L. O. (1973): Bayelsian Statistics for social scientists. Whitefriar Press. London p 215.

[16] Uwaezuoke, J. C., Ogbulie, J. N., Njoku, C. J., Obiajuru, I. O. C. and Njoku, A. J. (2000): Antibiotic Sensitivity Pattern of Bacterial Isolates from Poultry Feeds. International Journal of Environmental Health \& Human Development. 1 (2): 24-27.

[17] World Fish Centre (2003): Fish: An Issue for Everyone. A Concept Paper for Fish for All Global initiative, Penang Malaysia. p. 10. www.worldfishcentre.org. 